\title{
Surfaces
}

\section{Ethics without Foundations: the Question of Universalism Roundtable 5}

\section{Alessandra Tanesini}

Volume 7, 1997

LE FÉMINISME HORS DE LUI-MÊME

FEMINISM BESIDE ITSELF

URI : https://id.erudit.org/iderudit/1064813ar

DOI : https://doi.org/10.7202/1064813ar

Aller au sommaire du numéro

Éditeur(s)

Les Presses de l’Université de Montréal

ISSN

1188-2492 (imprimé)

1200-5320 (numérique)

Découvrir la revue

Citer cet article

Tanesini, A. (1997). Ethics without Foundations: the Question of Universalism: Roundtable 5. Surfaces, 7. https://doi.org/10.7202/1064813ar d'utilisation que vous pouvez consulter en ligne. 


\title{
Ethics without Foundations: the Question of Universalism Roundtable 5
}

\author{
Alessandra Tanesini \\ University of Wales \\ Cardiff
}

Surfaces Vol. VII.114 (v.1.0A - 28/06/1997) - ISSN: 1188-2492

Copyright for texts published in Surfaces remains the property of authors. However, any further publication should be accompanied by an acknowledgement of Surfaces as the place of initial publication.

Feminism has a very diverse history: it has been thought, practised and developed in the streets, in academia, in women's shelters, and at conferences[ $\underline{1}$ ]. In all of its forms, however, feminism is a movement that embodies a moral vision about the status of women in society. It is, I believe, a duty of the feminist academic as a social critic to articulate this moral vision, to understand what feminism as an ethics amounts to. In this paper, I do some of the preliminary work necessary to the articulation of the ethics of feminism.

The choice of ethics, rather than politics, as the crucial question in feminism is no longer new.[ $\underline{\mathbf{2}}$ ] It does not, however, involve denying that feminism is, first and foremost, a political practice. Feminist politics, on the one hand, are always instantiated in localised contexts, and it is only within these contexts that they are open to discussion and negotiation. Ethics as the articulation of the moral vision of feminism, on the other hand, allows discussion to proceed at a more general level. 
At this point, feminists who have been trained to distrust master narratives and claims about the universality of the subject might already fear that foundationalism and universalism will soon raise their ugly heads. After all, my invocation of ethics seems to serve the sole purpose of providing universal grounds on which to base political claims. I am not going to declare my complete innocence of these intellectual sins; I am, in a sense, guilty as charged. Nevertheless, I would like to explain what, in my case, these charges would amount to, before any verdict is passed.

Foundationalism has assumed many shapes in its long history, but in its undiluted form it amounts to an assertiwhilst not in themselves in need of any justification, validate the whole intellectual edifice that is built upon them. In another sense, however, the foundations are simply the starting point for one's thinking; in this second sense, foundationalism is simply inevitable. We need to start thinking from somewhere, even if that somewhere is in medias res.

However, I am not just proposing to start my thinking from ethics; I am suggesting that ethics might ground politics. Nevertheless, I am not advocating undiluted foundationalism because I am not endorsing the view that ethics stands in no need of either justification or articulation. But what about ethics itself? Does it have foundations?

It is at this point that universalism has usually been deployed: claims about a supposedly universal subject have been taken as grounding supposedly universal moral principles. Yet the subject so described is anything but universal, and the results of this move, although at times locally beneficial, have been, in general, quite disastrous.[ $\underline{\mathbf{3}}$ ]

Solidarity has appeared to some to provide an alternative to universalism in ethics.[ $\underline{\mathbf{4}}$ ] Solidarity is invoked because it is compatible with the deconstruction of the universal subject of much traditional thinking in morality. Although I am quite sympathetic to these positions, and believe that solidarity is an important value for an ethics of feminism, I do not think that disbelief in the universal subject requires a move to an ungrounded notion of solidarity. That is, I believe that it is possible to preserve some space for universalism in ethics whilst rejecting the universal notion of the subject. 
The myth of the universal subject is a belief in an essentialist conception of the human being.[ $\underline{\mathbf{5}}$ ] It is the belief that there are features, such as reason, by virtue of which one is human. Possession of these features legitimizes entitlement to a set of rights that are universal because they pertain to a subject just in virtue of its humanity. Hence, it is the essentialism implicit in this conception of the subject that carries the whole theoretical weight of traditional universalism. Essentialisms of this kind are untenable, and they have been convincingly criticised.[ $\underline{\mathbf{6}}$ ] Abandoning essentialism, however, does not require a rejection of universalism. [ 7 ] Instead, it is possible to endorse a universalism without essentialism, that is, a universalism without foundations.

Traditional universalists, and more recent supporters of an ethics of solidarity share at least two presuppositions: both assume that universal moral claims, if they exist at all, are grounded on self-legitimising a priori truths; both also assume that only a metaphysical theory of the subject could provide such grounds. Belief in the viability of a metaphysics of the subject leads traditional universalists to endorse universal moral claims, whilst disbelief in that metaphysics leads supporters of solidarity to the opposite conclusion.

I would like to suggest, instead, that universalism in ethics does not require a grounding in metaphysics. The universalism I advocate is rather cautious; it merely asserts the legitimacy of making some universal claims in the realm of ethics. It is a universalism compatible with the acknowledgement of the ever present possibility of error. It is also a contingent universalism because it takes the validity of universal claims as being subject to change. What is valid now might have been otherwise and, perhaps, will cease to be valid at some point in the future. In other words, it is a universalism which does not rest on a priori foundational truths, and does not stem from essentialist claims.

This is a universalism which, to quote Butler, acknowledges that:

what one means by 'the universal' will vary.... This is not to say that there ought to be no reference to the universal or that it has become, for us, an impossibility. On the contrary. All this means is that there are cultural conditions for articulation which are not always the same, and that the term gains 
its meaning for us precisely through the

decidedly less-than-universal cultural

conditions of its articulation.[ $\underline{\mathbf{8}}$ ]

Although I find Butler's reifying language unhelpful here, I believe she is correct in identifying a sort of universalism that is historically and locally contingent, neither aspiring to transcendental status, nor relying upon essentialist premises.

Moral discourse about values, rights, and duties is part of normative discourse. It aims to legislate and legitimize practices and stances, rather than to describe them. It is a discourse about 'ought' rather than 'is.' Normative claims express judgments about how we should develop our current practices, functioning as endorsements either of the status quo or of change. In either case, they always emerge from, and are enabled by, an all too localized context of background practices.[ $\underline{\mathbf{9}}$ ] Hence, a universal moral claim is simply an endorsement of generality concerning the emendation or the preservation of some current moral practices. It remains a fallible and contingent claim that bears the marks of its historical and social genesis.

The contingent and fallible character of such claims does not foreclose their possible legitimacy. These claims could still be validated, albeit not definitively and not for all times; the source of their legitimation is to be found not in an a priori metaphysics but in the current practices of validation that are themselves open to normative emendation.

I am thus committed to some sort of foundationalism in so far as I preserve a substantive notion of validity. Moral claims have grounds that legitimize them: these grounds might belong to other moral and political, epistemic, and even descriptive discourse. These foundations, however, are contingent because they can be rejected, or become themselves grounded on something else. Current practices are the rock bottom of moral and epistemic discourse, but this rock bottom is also a floating raft where everything can be changed (but not all at once, nor by an act of pure will). 


\section{NOTES}

1. I would like to thank all other speakers at that conference for many interesting conversations.

2. See Drucilla Cornell, Beyond Accommodation (New York: Routledge, 1991) and Diane Elam, Feminism and Deconstruction (London: Routledge, 1994).

3. For a critique of this position see Seyla Benhabib, The Generalized and the Concrete Other, Situating the Self (Cambridge: Polity Press, 1992), pp. 148-177.

$\underline{4}$. See Richard Rorty, Contingency, Irony, and Solidarity (Cambridge: Cambridge University Press, 1989). Elam in Feminism and Deconstruction argues for an ethics of groundless solidarity; her position, however, is rather different from Rorty's. Also, her view is compatible with some sort of universalism in ethics, because she advocates a solidarity which is based on shared ethical commitments (p. 109); that is, her notion of solidarity is grounded on (contingent) foundations.

5. See Jane Flax, Thinking Fragments (Berkeley: University of California Press, 1990), p.32.

6. See, as an example, Elizabeth Spelman, Inessential Woman (London: The Women's Press, 1990).

7. I owe to Naomi Schor the point that many feminist attacks of universalism are best construed as arguments against essentialism.

8. For a Careful Reading, Feminist Contentions (New York: Routledge, 1995), p.129.

9. For a more extensive treatment of these issues see Mark Lance and John Hawthorne, The Grammar of Meaning (unpublished manuscript), and my Whose Language? , Knowing the Difference, ed. by Kathleen Lennon \& Margaret Whitford (London: Routledge, 1994), pp. 203-216.

Accueil Surfaces | Table des matières | Recherche Surfaces Home Page | Table of Contents | Search

PUM | Livres | Revues | Publications électroniques | Vente et distribution 